\title{
Museums and Transitional Justice: Assessing the Impact of a Memorial Museum on Young People in Post-Communist Romania
}

\author{
Duncan Light $^{1}\left(\mathbb{D}\right.$, Remus Creţan ${ }^{2, *(\mathbb{D})}$ and Andreea-Mihaela Dunca ${ }^{2}$ \\ 1 Bournemouth University Business School, Bournemouth University, Poole BH12 5BB, UK; \\ dlight@bournemouth.ac.uk \\ 2 Department of Geography, West University of Timisoara, 321322 Timisoara, Romania; \\ andreea.dunca@e-uvt.ro \\ * Correspondence: remus.cretan@e-uvt.ro
}

check for updates

Citation: Light, D.; Creţan, R.; Dunca, A.-M. Museums and Transitional Justice: Assessing the Impact of a Memorial Museum on Young People in Post-Communist Romania. Societies 2021, 11, 43. https://doi.org/10.3390/soc11020043

Academic Editor: Gregor Wolbring

Received: 1 April 2021

Accepted: 6 May 2021

Published: 12 May 2021

Publisher's Note: MDPI stays neutral with regard to jurisdictional claims in published maps and institutional affiliations.

Copyright: (c) 2021 by the authors. Licensee MDPI, Basel, Switzerland. This article is an open access article distributed under the terms and conditions of the Creative Commons Attribution (CC BY) license (https:// creativecommons.org/licenses/by/ $4.0 /)$.

\begin{abstract}
Memorial museums are frequently established within transitional justice projects intended to reckon with recent political violence. They play an important role in enabling young people to understand and remember a period of human rights abuses of which they have no direct experience. This paper examines the impact of a memorial museum in Romania which interprets the human rights abuses of the communist period (1947-1989). It uses focus groups with 61 young adults and compares the responses of visitors and non-visitors to assess the impact of the museum on views about the communist past, as well as the role of the museum within post-communist transitional justice. The museum had a limited impact on changing overall perceptions of the communist era but visiting did stimulate reflection on the differences between past and present, and the importance of long-term remembrance; however, these young people were largely skeptical about the museum's role within broader processes of transitional justice. The paper concludes that it is important to recognize the limits of what memorial museums can achieve, since young people form a range of intergenerational memories about the recent past which a museum is not always able to change.
\end{abstract}

Keywords: memorial museum; transitional justice; young people; visitors/non-visitors; communism; Romania; intergenerational memory

\section{Introduction}

In recent decades, issues of memory, remembrance and memorialization have become central themes within social science research and "memory studies" is now an established interdisciplinary field [1]. Underpinning this development is a recognition that memory and remembering are as much social as individual practices. As Laanes and Meretoja [2] (p. 3) argue, memory "is not merely an individual, psychological process that takes place in our 'heads' but is always already mediated by culturally and socially shaped memory forms". Much recent research takes Maurice Halbwachs' concept of "collective memory" [3] as its starting point and has explored the various ways in which social remembrance takes place. It is widely recognized that societies make choices about what (and what not) to remember. Associated practices of memorialization are intended to "concretize" particular ways of understanding the past in specific sites or locations such as monuments or museums [4,5]. Memory and remembering are, therefore, as much about the present as the past [6].

One context in which issues of memory and memorialization have particular importance is in societies which have recently experienced conflict, genocide, repression, authoritarian rule, or other forms of political violence. Many such societies have embarked on a process of "transitional justice" which is intended to reckon with the recent past. Transitional justice embraces a range of measures $[7,8]$ intended to build democratic institutions founded on human rights. These measures include reforming the justice sector and 
promoting the rule of law; ensuring that perpetrators of violence are brought to account; establishing and acknowledging the nature of the violence that took place; and, sometimes, to bring about reconciliation and peace between former enemies. These instruments are intended to establish "a moral and political break with a repressive, non-democratic past" [9] (p. 360).

Memorialization is a central process of transitional justice [6,7]. Some societies may choose to forget or bury recent political violence, but in many instances there is an active strategy to commemorate such violence. Sites of remembrance can achieve a variety of ends [10-13] including acknowledging and honoring the victims of violence, contributing to reconciliation, and affirming collective belonging and facilitating broader civic engagement. A commonplace practice of memorialization is the establishment of memorial museums dedicated to recent conflict or political violence. These institutions have an explicit focus on "public pedagogy" [14] (p. 10) that is intended to have a broader societal impact [15]. Such museums aim to facilitate understanding and remembrance, strengthen democratic values and tolerance, change the views and attitudes of visitors so that they reject violence, educate future generations about past violence, and legitimize the regime currently in power [13]. Transitional justice museums are part of a broader trend towards museology which advocates social activism and progressive social change [16]. With their focus on both public education and memorialization, transitional justice museums are closely aligned with peace museums and human rights museums [17-19].

Yet, for all the importance attached to transitional justice, there has been limited attention to whether transitional justice instruments "work" or have an impact on wider society [20-25]. The same issue applies to transitional justice museums [15]. Apart from a few isolated studies, there has been limited investigation into the ways that visitors engage with the displays and messages that they encounter in such museums, and whether museums succeed in bringing about the changes in attitudes and values that are often claimed for them. The contribution of memorial museums to transitional justice project is, therefore, an issue which requires further investigation.

This paper examines this issue with reference to a memorial museum in Romania which interprets the repression and hardship of authoritarian communist rule (1947-1989). We begin by reviewing recent academic debate about the role of museums within transitional justice projects. We then introduce an empirical study of how young Romanians (who have no direct experience of living under communism) respond to the museum. In previous papers [26,27], we have examined the experiences of young people when visiting the museum. Here, we seek to explore the impact of the museum in more detail by comparing the responses of those who had visited the museum with those who had not. We argue that, whether or not they had visited the museum, these young people were far from ignorant about the communist past. Instead, they had formed a range of second-hand or intergenerational memories of the communist period (largely from talking to their families) and this knowledge shaped and mediated their experiences when visiting the museum. In particular, these young people did not uncritically accept the museum's condemnation of the communist regime.

\section{Literature Review: Memorial Museums and Transitional Justice}

Williams [15] argues that recent decades have seen the emergence of a new type of museum: the memorial museum which he defines as "a specific kind of museum dedicated to a historic event commemorating mass suffering of some kind" (p. 8). Such museums interpret episodes of violence, repression, or conflict for both present and future audiences [13]. Memorial museums have a number of distinctive characteristics [15]. First, their structure is often central to their identity, since many are housed in buildings (such as prisons or detention centers) formerly associated with suffering, repression, or atrocity. Second, whilst catering for diverse audiences, they frequently have a special relationship with the victims of mass suffering, who may be key stakeholders and sometimes volunteers or employees. Third, they may regularly host memorial events and activities intended 
to commemorate the events which they interpret [16]. Fourth, they frequently have an additional role as research centers dedicated to understanding the events around which they are themed. Finally, they have an overtly pedagogic mission, being intended to morally educate visitors about past violence and suffering see also [13].

Museums can contribute to transitional justice projects in various ways [13]. First, they are a mechanism of truth-telling about the recent past, ensuring that there is a public record of recent political violence (for this reason memorial museums are often integrated with research centers). Second, memorial museums are places of acknowledgement and remembrance of the victims of violence. In this role they provide a form of symbolic reparation [12] for victims. Museums are intended as a resource for particular communities and stakeholders such as victims and survivors (and their relatives). They aim to support healing and closure [28]. Third, memorial museums aspire to the moral education of their visitors [13]. They aim to encourage visitors to reject violence and embrace tolerance, democratic values, and human rights $[16,18]$. In particular, memorial museums assert the message of "never again", which underpins transitional justice [25]. In short, memorial museums seek to be instruments of social change [16] and political persuasion [14], where they are intended to provide transformational experiences for their visitors [13,29].

Memorial museums need to tread carefully when addressing recent political violence. In societies which have experienced conflict or repression, the recent past may be an emotive and divisive issue and one that is subject to multiple interpretations. Consequently, commemorative activity needs to recognize these complexities and allow for nuanced interpretations of recent events [11,12]. Consequently, some memorial museums set out to avoid polarization. Instead, they present narratives from multiple perspectives (often including minority or marginalized social groups) in order to encourage reflection, debate, and dialogue among visitors [18,30]. The intent is to encourage engagement and exchange in a way which will create a better present and future [13]; however, this approach may fragment the process of remembering and result in a lack of consensus about how the recent past should be approached [25]. Conversely, other memorial museums take the opposite stance and present unambiguous moral criticism (or even condemnation) of the former regime and its criminality $[18,31]$. The societal response to a memorial museum (and its potential contribution to transitional justice and social reconstruction) will therefore depend on broader attitudes to recent political violence, the desire for accountability and reconciliation, and also the time that the museum was established relative to the events that it interprets [10].

Since they are focused on issues rather than objects [16], memorial museums are distinctive in terms of their display approach. In particular, they frequently rely on "theatrical tropes" [15] (p. 97) and strategies which are experiential and affective [13]. This may be achieved through the provision of interactive or virtual exhibits [18] and other approaches such as the use of elaborate reconstructions. Another strategy is the provision of opportunities for visitors to share in the experience of victims of violence (such as being alone in a prison cell). These approaches can be amplified through careful use of sound effects and music, while narrow corridors and low lighting can create a sense of claustrophobia [13]. In short, memorial museums focus on creating immersive, embodied experiences [15,32] which are intended to have a profound impact on the visitor.

Furthermore, because memorial museums are intended to highlight human rights abuses, they put the lived experiences of the victims of violence at the center of their presentations [33]. This focus on human stories is part of a trend among memorial museums (along with peace museums and human rights museums) to embrace a more emotive approach to communicating ideas [16]. A range of techniques are used to assert the humanity of those who experienced political violence, including lists of names, photographs, eyewitness testimonies, and ordinary objects belonging to victims [13]. Strategies which engage the visitor in a direct and visceral way are intended to produce an emotional response by unsettling visitors [34]. By positioning the visitor as a witness to the suffering of others [29,32], memorial museums challenge their audiences "to find empathy and 
compassion within themselves" [18] (p. 229). Pushing visitors to identify with and develop empathy for the victims of political violence has the potential to lead to powerful learning experiences which, in turn, can bring about personal moral transformation [13].

Memorial museums established within transitional justice projects will attract a diverse audience [26], but an important distinction can be made between citizens with first-hand experience of past political violence and later generations with no such experience. Educating the latter group is central to transitional justice $[27,35]$ to ensure that past suffering is not forgotten. Consequently, a range of educational initiatives can be adopted to ensure that younger people are aware of the circumstances of past violence and the experiences of their parents and grandparents. Memorial museums can have a particularly important role to play in such initiatives $[16,27,36]$.

Yet, informing and educating those without first-hand experience of political violence may be more problematic than at first glance. McGhie et al. [37] highlighted the importance of "psychological distance" within the experience of visiting museums. Psychological distance refers to "the perceived distance of an object or event in time, space, culture and probability" [38] (p. 111). When this distance is small, an individual is able to construe and make sense of events in a detailed and concrete way. Conversely, where this distance is greater, construals are more abstract, decontextualized, and less specific [39]. In a museum context, this means that the greater the distance between the visitor's experience and the events represented, the greater the effort required by the visitor to understand and make sense of the information presented. For example, Massara and Severino [38] reported that a higher psychological distance between visitors and a heritage site was associated with higher (more abstract and generalized) construals of the site. Ying et al. [40] reported that greater familiarity (that is, a reduced psychological distance) among museum visitors was associated with more mindful engagement during their visit. Therefore, a particular challenge for issue-based museums is to help visitors negotiate the distance between their own experience and the issue that is interpreted [37].

The issue of psychological distance assumes particular importance in the context of transitional justice. Museum visitors who have lived through political violence may have little difficulty in understanding the presentation of past violence that they encounter; however, young people without this direct experience may struggle to make sense of past events, and the context in which they unfolded $[10,11]$. In other words, memorial museums need to bridge the experiential difference [38] between a violent past and the lives of contemporary young people. Furthermore, this matter will become more significant as the temporal interval between a period of political violence and the present-day increases, since the psychological distance between young people and this period will also increase. Indeed, over time, young people may regard a period of recent violence in the same abstract way they do more distant historical events. One strategy to engage young people (which, as noted above, is commonplace in memorial museums) is through the provision of experiences which are as much emotional as cognitive [41]. Through a focus on victims of violence and their stories, younger visitors may be better able to understand, and connect with, past episodes of political violence.

For all the debate about memorial museums, relatively little is known about their impacts on visitors, or the broader ways that they work within transitional justice projects. Studies which critically interrogate the messages and display philosophy of individual memorial museums are commonplace (see [13] for example and the collection of chapters edited by Norris [42]), but there far less research has directly engaged with visitors and the nature of their encounter with political violence in a museum. The limited research into memorial museums specifically in the context of transitional justice has established that they can provide powerful emotional experiences for visitors (which can be transformational in some cases); increase awareness and understanding of the recent past; bring about a change in opinions and attitudes (about both the past and present); develop understanding and support for practices of remembering; and contribute to reconciliation [14,23,25,43-45]. More broadly, research regarding other forms of issue-based museums indicates that 
visiting can change attitudes and persuade visitors to think differently (e.g., Swim et al. [46] in the case of climate change). The question of how memorial museums established within transitional justice projects impact upon their visitors is, therefore, one which requires further investigation. This paper seeks to contribute to this debate.

\section{Materials and Methods}

The study aims to examine the impact of visiting a memorial museum on the attitudes and views of young people who have no first-hand experience of the violence that is interpreted. It specifically focuses on two issues: opinions about a former repressive regime and the role of memorial museums within transitional justice projects. These are issues which we have examined in previous research among visitors to a memorial museum [27]. In this paper, we extend this analysis through comparing the responses of visitors and non-visitors in order to examine the impact of visiting the museum in shaping these opinions.

The memorial museum in question is located in Romania and is entitled Memorialul Victimelor Comunismului şi al Resistenţei (Memorial to the Victims of Communism and to the Resistance). It is located in the northern town of Sighetu Marmaţiei and was established in a former prison that was used to incarcerate opponents of the communist regime during the 1940s and 1950s. The museum interprets suffering, repression, and hardship during Romania's period of Communist Party rule (1947-1989). Sighet Memorial Museum opened to visitors in 1997 and was an initiative of civil society actors who were determined to commemorate the human rights abuses of the communist regime. It was established in circumstances where many leading figures from the former regime remained politically active and showed little inclination to condemn or commemorate the recent past $[6,7,47]$. The museum uses more than 80 former cells to present visitors with displays about the human rights abuses committed by the communist regime. In common with many other memorial museums there is an emphasis on human stories, and a focus on the victims of communist repression. Sighet Museum makes extensive use of photographs and personal testimonies of those who suffered under communism. There is some emphasis on experiential approaches to presentation in that visitors have the opportunity to experience life in prison (including being alone in an empty cell); however, the overall display approach relies heavily on text and photographs, with no use of interactive exhibits. Unlike many memorial museums, it does not seek to encourage debate and dialogue. Instead it unequivocally condemns the communist regime and the political violence committed in its name [48], while acknowledging and honoring the experiences of those who suffered. In 2019, the museum attracted 140,171 visitors, 28\% of whom were children and young people on educational visits (information supplied by the museum).

There are various approaches that can be adopted to investigate the impact of a museum visit. One approach (known as pre/post testing) is to interview the same visitors before and after their visit. This has the advantage of being able to identify individual changes in knowledge or attitudes that result from the visit; however, while commonplace in museum research, this approach has a number of disadvantages. The foremost among these is "pretest sensitization" [49] (p. 1091), in which the pre-visit interview can of itself change the way in which a visitor subsequently responds to the museum. In particular, the pre-test can raise awareness or trigger learning in a way which sensitizes the visitor to particular issues and topics that they encounter during the museum visit itself [50]. In the post-visit interview, visitors may respond based on remembering the questions (and their answers) that they were asked before the visit [51]. Given the unsettling nature of the presentations in Sighet Memorial Museum, we sought to avoid any pre-visit interviews which might alert the participants to the museum's content or change the ways in which they interacted with the various displays that they encountered.

An alternative approach is to interview two different groups of people: those who had visited the museum and those who had not. The non-visiting group is effectively a control or comparison group which provides a "comparative standard" against which the response 
of the visiting group can be judged [52] (p. 251). While this does not assess individual changes in attitudes or learning that occurred as a result of the museum visit, it does allow for comparisons between the visiting and non-visiting groups which, in turn, enables an assessment of the impact of the visit in shaping attitudes and opinions. An important consideration is ensuring that the visiting and non-visiting groups are closely matched in terms of various sociodemographic characteristics which can reduce the potential for bias [53]. This approach is less common within museums research but has been employed in studies of other issues-based museums (for example, [14,46,54,55]). It has also been employed in other studies focusing on the impact of transitional justice measures [21]. This approach was adopted in this study as a more appropriate method for assessing the impact of the museum visit.

The participants in the study were all final year undergraduate geography students at West University of Timişoara in the city of Timişoara in the west of Romania. Their final year of study included an elective fieldtrip (in September of 2017) to the Maramures region, which is where Sighet Museum is located. During the fieldtrip, these students visited the museum and several other attractions and features of geographical significance. Neither the fieldtrip nor their wider academic curriculum included a consideration of the communist past, so their academic study is not considered to have influenced their encounter with the museum. A second group of students from the same year group elected to not go on the fieldtrip. The student year group was comprised of 63 students, where 61 agreed to participate in this study. The "visiting" group was comprised of 43 of the 45 students who had visited the museum during the fieldtrip, while the 18 students who had not attended the fieldtrip constituted the "non-visiting" group. Some aspects of the experiences (both cognitive and emotional) of the "visiting" group have been reported elsewhere [26,27].

A qualitative approach to data collection was adopted, which sought to explore the views and responses of visitors and non-visitors to the museum in detail. This was achieved using focus groups, which have the advantage of being straightforward and inexpensive to develop and undertake [53]. They allow a detailed exploration of views and opinions, but also allow the consideration of group dynamics (such as agreement or disagreement) regarding a particular topic [56]. They are a versatile method of data collection in museum research [57]. Four focus groups were undertaken with the students who had visited the museum and two with the non-visiting groups. Participation was entirely voluntary although almost all students in the year group chose to take part. All participants signed a consent form prior to the focus group session commencing. During the focus group sessions (which lasted up to $90 \mathrm{~min}$ ), the participants were invited to discuss a range of open-ended questions which covered their knowledge of the communist past, their opinions about the communist regime and its actions, and their views on the role of the museum within post-communist transitional justice. The focus groups were recorded (with the full consent of participants) and were later transcribed (after which the audio recordings were deleted).

The focus groups were undertaken in a teaching room in West University in December in 2017. They were purposively undertaken two months after the museum visit in order to allow time for reflection among the visiting group. There is the possibility that participants in the visiting group may have learned more about the communist era and its repression during this two-month interval. Although we cannot eliminate this possibility, we consider it unlikely, since young Romanians generally have little interest in the communist past and do not give it much attention [27].

With a study involving comparisons between two groups, the similarity of the groups is an important consideration $(21,51,53)$. As Table 1 shows, the sociodemographic characteristics of the visiting/non-visiting groups were nearly identical. 
Table 1. Sociodemographic characteristics of the visiting/non-visiting groups.

\begin{tabular}{|c|c|c|c|}
\hline & $\begin{array}{c}\text { Visiting Group } \\
\quad(n=43)\end{array}$ & $\begin{array}{l}\text { Non-Visiting } \\
\text { Group }(n=18)\end{array}$ & Comments \\
\hline $\begin{array}{c}\text { Sex: } \\
\text { Male } \\
\text { Female }\end{array}$ & $\begin{array}{l}15 \\
28\end{array}$ & $\begin{array}{c}6 \\
12\end{array}$ & $\begin{array}{c}\text { No significant difference } \\
\text { between the groups } \\
\text { (Chi-square test, } p=0.97 \text { ) }\end{array}$ \\
\hline Average age: & 20.95 & 21.05 & $\begin{array}{l}\text { No significance } \\
\text { difference between the } \\
\text { groups (Mann-Whitney } \\
\text { U test, } p=0.81 \text { ) }\end{array}$ \\
\hline $\begin{array}{c}\text { Place of residence: } \\
\text { Timiş County (including } \\
\text { city of Timişoara) } \\
\text { Counties neighbouring } \\
\text { Timiş } \\
\text { Elsewhere in Romania }\end{array}$ & $\begin{array}{l}18 \\
11\end{array}$ & $\begin{array}{c}10 \\
4\end{array}$ & $\begin{array}{c}\text { No significant difference } \\
\text { between the groups } \\
\text { (Chi-square test, } p=0.59 \text { ) }\end{array}$ \\
\hline $\begin{array}{l}\text { Ethnicity: } \\
\text { Romanian }\end{array}$ & 43 & 18 & \\
\hline
\end{tabular}

An additional consideration is each student's family experiences of communism, since these could influence their attitudes to the communist past as much as the visit to the museum itself. Relatively few students recounted stories of traumatic events experienced by their parents/grandparents during the communist period (these usually concerned their grandparents being forced to give agricultural land to a collective farm). It is possible that other students were aware of such events from their family's history but chose not to mention them. Of the nine students who mentioned such family experiences, eight were in the visiting group and one was in the non-visiting group, but the difference between the groups was not statistically significant (Fisher's exact test, $p=0.26$ ). While we cannot discount that family experiences may have been more important in shaping opinions about the communist past than the museum visit, we do not consider that these experiences were a major influence on the views of these students.

The presentation of the research findings focuses on comparing the responses of the visiting and non-visiting groups in order to explore the impact of visiting the museum. This is undertaken here using both quantitative and qualitative approaches. To gain an initial indication of the differences between the visiting/non-visiting groups, the data were summarized using tables. The production of these tables involved coding individual responses to each question into 3 categories (usually "agree", "disagree", and "ambivalent"). The "ambivalent" category included both those who had mixed views and those who felt that they did not know enough to answer the question. This coding was based on both each participant's response to the question they were asked and their wider reactions to the focus group discussion. This coding was undertaken independently by two of the authors. When completed, the authors compared their analyses and, through a process of discussion and negotiation, agreed a final version of the categorization which was subsequently expressed as a table.

A Chi-square test for independence was employed to determine if there was a statistically significant difference between the responses of the visiting and non-visiting groups. This test is appropriate for data that is in the forms of frequencies within particular categories [58]; however, in some instances, the contingency table included observed values of zero or more than $20 \%$ of expected values below 5 . In such cases, the contingency table was reformed through combining appropriate categories and the test repeated. If the reformed table remained unsuitable for a Chi-square test, Fisher's exact test (employing a $2 \times 2$ contingency table) was employed instead [59].

The focus group data were also analyzed in a qualitative manner through coding the responses to individual questions with the codes being grouped into themes [60]. 
The responses of the focus group participants are illustrated using direct quotations from the discussions. These were translated from Romanian by the first author (a native English speaker) and each individual translation was checked by the second author (a native Romanian speaker) who suggested changes if appropriate. All names presented in the following analysis are pseudonyms.

The focus groups were supplemented with interviews with three key stakeholders. These were Ana Blandiana (the founding director of Sighet Memorial Museum), Ioana Boca (the executive director of Fundaţia Academia Civică (Civic Academy Foundation), the non-governmental organization which manages the museum), and Ioan Ilban (a former detainee in the museum). These interviews focused on the role, mission, and aspirations of Sighet Memorial Museum. They allow the responses of students to be understood with reference to what the museum seeks to achieve. All interviewees signed a consent form and gave permission to be quoted.

\section{Research Findings}

\subsection{Attitudes to the Communist Past}

Sighet Museum seeks to condemn the political violence committed by Romania's communist regime, particularly for a generation with no direct experience of communism. In order to examine the impact of visiting the museum, both groups of students were asked a number of questions about their perceptions of the communist past. The first focused on their general perception of the communist era. The responses of the visiting group have been considered elsewhere [27], but in this analysis we seek to add a comparison with the perspectives of the non-visiting group. The responses (coded as "negative", "ambivalent" or "positive") are presented in Table 2.

Table 2. Perception of the communist era among visitors and non-visitors to the museum.

\begin{tabular}{cccc}
\hline Perception of the Communist Era & & & \\
\hline & Visiting Group & Non-Visiting Group & Total \\
\hline Negative & 19 & 13 & 32 \\
Ambivalent & 19 & 2 & 21 \\
Positive & 2 & 2 & 4 \\
Total & 40 & 17 & 57 \\
\hline
\end{tabular}

Note. The figures for the visiting group are derived from [27]. Participants who did not give a response are excluded.

Around half of the participants viewed the communist past in negative terms. For example, Rubi (visiting group) stated the following: "Principally, I think that it was a negative period from almost all points of view". Similarly, Bera (non-visiting group) argued "from my point of view it was a terrible and sad period". However, there was a large minority of the participants with more ambivalent views. For example, Sara (visiting group) stated: "I know about communism mostly from my family. I remember how they talked to me about it. If I were to express my opinion I am somewhere between $50 \%$ negative and 50\% positive". Rada (from the non-visiting group) had a similar view:

I found out [about the communist period] both at school but also from my parents and grandparents. In my family for example, opinions were very divided: my parents didn't agree with it, they said it was a very ugly period ... while my grandmother is very happy only when she thinks about it ... My view of communism is neither positive nor negative.

A comparison of the responses of the visiting and non-visiting groups indicates a significant difference in the responses of the two groups $\left(\mathrm{X}^{2}=6.0,1 \mathrm{df}, p<0.05\right.$, "positive" category excluded). Those who had not visited were more likely to express negative views about communism, whereas those who had visited were more likely to express ambivalent views, despite having encountered the museum's unequivocal condemnation 
of communism. Indeed, when asked if they felt more negative about communism after their visit to the museum few of the visiting group agreed [27].

Such mixed opinions about the communist past are not unique to this study. Numerous press reports and academic studies have reported that many Romanians have ambivalent views about the communist past. Furthermore, many studies have identified that some sections of Romanian society express nostalgia for the communist era [61-64]. Furthermore, such positive appraisals of the communist past are not confined to those who lived through communism, since various studies have identified that many young people born after 1989 also think of the communist era in positive terms [65-67]. Similar findings have also been reported in other post-communist countries [68].

Clearly, these young people were not approaching the museum with no prior understanding of its subject [14]. Although they had no direct experience of communism, the psychological distance between them and the communist past was not as great as might be expected. Instead, this distance was mediated by the stories they had heard about their familial experiences during the communist era. Consequently, many had formed clear views about the communist past, illustrating the importance of broader sociocultural context in influencing the museum experience [69]. However, the director of the Civic Academy Foundation argued that many young Romanians have formed a very selective view of communism:

There are many who are nostalgic; they discuss with their parents, with their grandparents who forget to tell them the negative side of communism. Many only remember the fact that ... everybody had a job, and everybody had a house, but they forget to also explain what that house meant and what that job meant; they don't know that you were constrained by them. Ultimately there was no freedom of movement and there was the fact that you were allocated a job and you didn't know where you would end up. You might have to move from Satu Mare [a town in the northwest of Romania] to Constanţa [a town in the far east of the country] and you had to leave your family. They're not told this, so they see only one side of the story-where there's certainty about tomorrow.

(Ioana Boca, Interview)

This form of intergenerational transmission of knowledge about a traumatic past has been termed "postmemory" by Hirsch [70,71]. She argues that the generation born after a period of collective trauma can form an emotionally powerful body of knowledge about past events that is so vivid as to equate to personal memories. Such postmemories are predominantly transmitted within the family in the space of the home [72]. The young people in this study had developed a range of understandings of the communist past which, in some cases, corresponded to postmemories; however, not all of these secondhand memories of communism were framed around traumatic experiences. In some cases, individual families may have had an easier time under communism leading to more positive memories. In other cases, these students had encountered their grandparents nostalgic recollections of the communist era which had shaped their understanding of the recent past. Indeed, Wildschut et al. [73] have argued that nostalgia can also be transmitted intergenerationally.

In addition to the stories about communism that these students had heard from their parents and grandparents, another important consideration is their personal experiences of life in the post-communist period. In particular, many expressed disappointment or disillusionment with their current lives and prospects. Only one-third felt that the postcommunist present was better than the communist period, and more than half had mixed views about the present compared with the communist past. Their experiences were framed and juxtaposed against the stories they had heard from their parents and grandparents about the perceived certainties of communism. Many spoke about life in contemporary Romania as a struggle. For example, Vica (visiting group) argued the following: "It seems to me that now, compared to the communist period, is a disaster. We have everything that we need but at the same time we don't have the money to buy even what we need 
or what we want". Similarly, Bran (non-visiting group) claimed that he had "much more freedom, without all those restrictions but with an empty pocket". Others spoke of the difficulties of finding a job or accommodation, again framed against their understanding of the communist era. Didi (visiting group) pointed out: "many young people finish their studies and they don't have a job; there are rather few jobs compared with the communist period". Amir (visiting group) argued: "from the point of view of work, you no longer have a guaranteed job. You've got to fight with 1000 other people for the same post ... and it depends on the acquaintances that you have, and work experience and so on". Others highlighted the difficulties of securing accommodation. Nica (visiting group) stated:

One example would be the fact that after working for a while, not long, my grandparents were given an apartment. As for us, we don't know if we'll ever have one ... today we'll have to go to the bank. You'll have to pay back the bank for your whole life to be able to buy an apartment or a house.

Some participants expressed dissatisfaction with broader aspects of contemporary life. Hara (visiting group) drew attention to the general disorder and upheaval that characterized the present: "there's no longer any order. It's a total chaos". Some expressed disillusionment with capitalism, such as Lola (visiting group) who lamented: "these days nobody pays any attention to anything-except money". Others questioned the state of Romania's post-communist democracy, such as Iris (visiting group) who claimed: "I for one don't believe that my vote counts in the sense that I consider that all of them, all that political system, they choose among themselves. I don't believe that my vote counts".

These sorts of view indicate how students cannot avoid making comparisons between their contemporary experiences and the pervasive stories of life under communism that had been recounted within their families [27]. This does not necessarily mean an idealization of the communist past, nor a nostalgia for communism. Most of these young people did not appear to think that the communist era was better. Indeed, they were universally aware of the restrictions on freedom of expression and movement that characterized the communist regime, but many appeared to consider that their everyday lives were not obviously better than those under communism (as they understood it). They recognized that the organization of everyday life could be different from their own experiences which are predominantly characterized by uncertainty. Many of these students were attracted by the possibility of a life with more certainty, but the only example of which they had knowledge was the Romanian communist period.

What this means is that these young people were far from ignorant about the communist past when they visited Sighet Memorial Museum. While they had relatively little interest in the communist period, their wider understandings of the recent past will have mediated the way that they interacted with, and interpreted, the museum's presentation of communist-era trauma. As Hamber [36] notes, visitors do not uncritically absorb the messages of memorial museums but instead construct their own meanings [69], in this case drawing from other sources of trusted knowledge about the past. Among some of those who had visited, the museum's presentations were not able to overturn stories and narratives received and transmitted within the family. This illustrates how a museum established as part of a transitional justice project does not have a monopoly on the presentation of past trauma and instead is effectively in competition with other narratives and sources of knowledge about that past [27].

While these young people had a wide body of background knowledge about the communist regime, this was mostly confined to issues of everyday life as experienced by their parents and grandparents. They had heard much less (if anything) within their families about the human rights abuses committed by the communist regime. Sighet Memorial Museum was established in order to highlight these abuses and to underline the criminality of the communist regime. To explore further whether visiting the museum had influenced the way these young people thought about the communist past the focus group participants were asked if they thought that communism was a criminal system. 
The responses were coded into the categories of "yes", "no", and "ambivalent" and are presented in Table 3.

Table 3. Responses to the question "do you think that communism was a criminal system"?

\begin{tabular}{cccc}
\hline & Visiting Group & Non-Visiting Group & Total \\
\hline Yes & 14 & 11 & 25 \\
Ambivalent & 7 & 1 & 8 \\
No & 2 & 6 & 8 \\
Total & 23 & 18 & 41 \\
\hline
\end{tabular}

Note. This question was not asked with one of the focus groups with students who had visited the museum. Participants who did not give a response are excluded.

Overall, over half of the students agreed with the question for a range of reasons. Some highlighted the human rights abuses committed by the communist regime. For example, Rubi (visiting group) contended: "I think it was a criminal system because many people suffered, some even died". Didi (visiting group) stated: "yes, because it was based in large part on the control of the people and the elimination of those who opposed them". Similarly, Fifi (non-visiting group) claimed: "it was certainly a criminal regime and a regime which imposed itself through brutality, in the course of which many people died". Other students highlighted restrictions on the freedom of expression. For example, Vova (visiting group) stated: "they didn't allow people to form their own opinions", a point echoed by Bobi (visiting group): "people could be free in thought, but not in expression". These responses indicate that, whatever positive views they may have heard from their families, these students recognized the repressive nature of the communist regime.

However, a minority of the students were again ambivalent. Some drew a distinction between the ideals of communism and the way it was put into practice in Romania. For example, Tedi (visiting group) argued: "on paper, communism seems to me the most ideal political system, but it can't be interpreted in such a totalitarian way. Communism in Romania (as in the other countries) was taken to the extreme". Gino (also in the visiting group) expressed a similar view: "I don't think that communism in itself, namely the ideas that it has, the ideology and all that, is a criminal system, but the way in which it was put into practice, yes". Iris (non-visiting group) echoed this point: "I don't think the system itself was criminal, as much as the people who lead that system and their mania for persecution". Other students were uncertain about the nature of the communist regime. For example, Mama (non-visiting group) stated: "I can't say that it was a criminal regime because nobody from that time was condemned for crimes against humanity undertaken in the name of communism or by the communist order, but categorically it was a restrictive and closed regime because you didn't have freedom of speech".

A small number of students (mostly in the non-visiting group) did not accept that communism was a criminal system. For example, Anda (non-visiting group) stated: "no, it wasn't criminal, but it was a closed system". Others were prepared to defend the actions of the communist leadership. Lulu (non-visiting group) contended:

I don't think that it was a criminal system because...for example, Ceaussescu didn't want bad for the country and before the revolution erupted he did everything possible to pay the [foreign] debt and for Romania to remain without debt, and I think that he wanted the best for the country, even if it was strict.

A Chi-square test indicated that there was no statistically significant difference in the responses of the visiting and non-visiting group $\left(\mathrm{X}^{2}=0, p>0.05\right.$, "ambivalent" and "no" categories combined). There were no differences between the two groups in the examples used to illustrate their views. In particular, the group that had visited the museum was not more likely to refer to issues of imprisonment or persecution within their responses. As noted above, most of those who did not accept the criminality of the communist system were in the non-visiting group; however, the museum did not persuade all those who visited of the criminality of the communist regime, and some drew a distinction between 
the concept and the practice of communism. These findings again indicate that, despite the museum's rhetorical presentation of communism, many of these young people were free-thinking critical agents who were able to come to their own conclusions about the nature of the communist regime.

Transitional justice is underpinned by the notion of "never again", i.e., that learning about past violence will prevent it recurring in the future [36]. Therefore, memorial museums which interpret political violence are as much about provoking reflection on the present and future as they are about the past $[13,17,74]$. Indeed, this was explicitly recognized by the museum's founder who argued: "I have always said that the Memorial is not a path to the past, but to the present and future because the first problem is to understand, to understand communism, so that we can identify its remnants in today's society" (Ana Blandiana, interview).

To investigate whether visitors to the museum had reflected on the relationships between the past, present and future the focus group participants were asked if there was a possibility that Romania could experience communism again. Table 4 presents a summary of responses, again coded as "yes", "no", or "ambivalent".

Table 4. Responses to the question "can you ever see Romania again experiencing a period of repression like the communist period"?

\begin{tabular}{cccc}
\hline & Visiting Group & Non-Visiting Group & Total \\
\hline Yes & 6 & 0 & 6 \\
No & 29 & 15 & 44 \\
Ambivalent & 8 & 3 & 11 \\
Total & 43 & 18 & 61 \\
\hline
\end{tabular}

Some students considered that a return to a period of repression was possible, although responses tended to be focused around the claim that "anything might happen" rather than a conviction that Romania could return to communism; however, almost three-quarters of the participants did not think that Romania would again experience communist repression while, once again, a minority were ambivalent. There was no statistically significant difference between the visiting and non-visiting groups (Fisher's exact test, $p>0.05$, "no" and "ambivalent" categories combined). There was a difference in the nature of the responses given by those who had, and had not, visited the museum. The visiting group showed evidence of understanding and reflection about the difference between Romania under communism and Romania today. For example, Zena stated: "I don't think that we could ever arrive again in communism. I am of the view that we've evolved and it would be impossible to make the same mistakes". This idea was echoed by Manu who argued: "I don't think so, because Romania has learnt from the mistakes which it made in the past". A related point was the importance of learning from the experiences of those who had lived through communist rule. For example, Rubi claimed the following:

I don't think that the communist period could return, principally because the mentality of people is different, especially that our parents lived in that period and it was something negative for them. But us, we've grown up with what they've taught us, and no, I don't think that it could be repeated.

A similar argument about how young Romanians were different from their parents was made by Mimi: "I don't think that we could return to communism, especially since half the population didn't live in that period and young people are much freer, they have completely different ideas compared with our parents and grandparents". Bebe made a different form of comparison between the past and present:

I don't think it would still be possible-at least not from the perspective of today's Romanians, I don't think that they would tolerate such a period ... at least they have the right to choose through a free vote the political system that they want. 
There were laws in the communist period, there are laws today, but today human rights are respected, and the right to choose their own leader.

Conversely, those who had not visited the museum tended to argue in more general terms that Romania was unlikely to return to communism. Simi argued the following: "I don't think so ... well, because people have changed, and I don't think that we'll arrive back where we started". Tata based his argument on Romania's membership of the EU: "However long I live, I'm 100\% convinced that we won't see communism again in Romania. Why? Because we're in the European Union and those in Brussels would not let such a thing happen". Lulu claimed: "I agree that Romania won't return to that regime because it would be too radical a change, and people wouldn't agree with it ... they would take to the streets to protest".

Here, there is evidence of the impact of visiting the museum. Many of those who had visited appeared to have developed a fuller and more nuanced understanding of communist repression which enabled them to reflect more fully on differences between the past and present. Many were able to make comparisons between communist and post-communist Romania in terms of human rights and freedoms. They also recognized communism as a reference point against which to judge the present, whilst also acknowledging the importance of learning from the past. The encounter with the museum had also shaped the way that they thought about the future [13]. As a result of the reflection and memorywork which they had undertaken they were convinced that Romania would never return to the extreme form of political order that communism represented.

\subsection{The Broader Role of the Museum within Post-Communist Transitional Justice}

As noted above, memorial museums are not only about the past, but they also speak about (and to) the present and future. Therefore, in addition to their role in memorializing the violence of the past, museums can also contribute to broader transitional justice processes of democratization. As Sodaro [13] (p. 4) argues, memorial museums aim to instill in their visitors an understanding of, and appreciation for, democratic values "by demonstrating the violence that results from the lack of these values". In this way, memorial museums have the potential to be "performances of democracy" [10] (p. 14). Moreover, previous research has indicated that visiting a memorial museum can increase support for democratic institutions [44].

The activists behind Sighet Memorial Museum clearly envisaged a role for the museum in strengthening democracy in post-communist Romania. The museum's founder argued the following:

In terms of the rule of law, yes, it's clear that the Museum is a place in which ... you can understand what happens if there is no rule of law; if the law is no longer law, if hypocrisy or simply the interests of certain people can annihilate everything around them.

(Ana Blandiana, interview)

Similarly, the director of the Fundaţia Academia Civică, which manages the museum, contended the following:

If you want to understand Romania today you need to visit the Memorial, because if we don't understand what happened to us, I don't think that we can head into the future ... I think that it's important (especially for young people) to understand how important are democratic values and the rule of law, and how easily they can be lost if you're not careful and if you don't defend them.

(Ioana Boca, interview)

To explore this issue in more detail, the focus group participants were asked for their views about the role of Sighet Memorial Museum within broader processes of transitional justice in Romania. Students were asked firstly if they considered that the museum could contribute to post-communist democratization in Romania. In addition, they were asked for their views on whether the museum could contribute to healing the memories of 
communist repression. Again, the responses of the visiting group have been reported elsewhere [27] and in this analysis we are adding the perspective of the non-visiting group. The views of the students (again coded as "yes", "no", and "ambivalent") are summarized in Table 5.

Table 5. Student views on the broader contributions of the museum to transitional justice in Romania.

\begin{tabular}{|c|c|c|c|c|c|c|}
\hline & \multicolumn{3}{|c|}{$\begin{array}{c}\text { Can the Museum Contribute to the Consolidation of } \\
\text { Democracy in Romania? }\end{array}$} & \multicolumn{3}{|c|}{$\begin{array}{c}\text { Can the Museum Contribute to Healing the Painful } \\
\text { Memories of the Communist Period? }\end{array}$} \\
\hline & Visiting Group & Non-Visiting Group & Total & Visiting Group & Non-Visiting Group & Total \\
\hline Yes & 22 & 14 & 36 & 6 & 1 & 7 \\
\hline No & 7 & 1 & 8 & 35 & 16 & 51 \\
\hline $\begin{array}{c}\text { Ambivalent/do } \\
\text { not know }\end{array}$ & 13 & 3 & 16 & 1 & 0 & 1 \\
\hline Total & 42 & 18 & 60 & 42 & 17 & 59 \\
\hline
\end{tabular}

Note. Participants who did not give a response are excluded.

Although over half the participants agreed that the museum had a role in the consolidation of democracy in Romania, opinions were mixed, and a significant minority of the participants disagreed or were ambivalent. There was no statistically significant difference in responses of the visiting and non-visiting groups $\left(\mathrm{X}^{2}=3.37,1 \mathrm{df}, p>0.05\right.$, "no" and "ambivalent" categories combined). Whether or not they had visited, those who considered that the museum could contribute to post-communist democratization tended to focus on its role in in presenting visitors with the actions of a regime which represented the very opposite of democracy. For example, Cara (visiting group) stated: "We already know what happened and we can avoid the same things and getting in such a situation [again]". Similarly, Dina (non-visiting group) claimed: "Yes, I think it can contribute, because that museum is actually an expression of the opposite of democracy and then people can see how it was, and what consequences it had". Iubi (non-visiting group) contended that the museum "shows us what people then didn't have, the things which they couldn't enjoy or experience, in comparison with what happens today. We have the right to vote, to freedom, to free expression regardless of what your opinion is".

Other participants were more skeptical. Aria (visiting group) argued: "to be able to change democracy it [the museum] needs a bigger impact", a point echoed by Gigi (visiting group) who stated that: "it can't be only this museum. It would need something else". A more pessimistic view was expressed by Tata (non-visiting group): "My response is no, because no museum in the world can contribute to the consolidation of a democracy. In order to consolidate a democracy we need to contribute, the people, the state itself. Or if a museum (whatever it is) can contribute, it can contribute very, very little".

Memorialization projects are seen as having a key role to play in the establishment of a democratic culture [11,25]; however, the young people here (whether or not they had visited) had mixed views about the role of a memorial museum within broader processes of transitional justice and a significant minority were unconvinced about the museum's contribution to democratization. This is not to say that museums cannot contribute to processes such as democratization, but rather that its role was not always obvious for this group of young people.

The participants were also asked if the museum could contribute to healing painful memories of the communist era (see Table 4). As reported elsewhere [27] very few of those who had visited the museum considered that the museum could contribute in this way. The non-visiting group responded in a similar way and there was no statistically significant difference between the two groups (Fisher's exact test, $p>0.05$, "no" category excluded). For example, Iubi (non-visiting group) argued: "I don't think either that this sort of memorial museum can heal painful memories because what happened - the events-are kept in the memory of those who lived and I don't think it's possible to heal the memories through the establishment of a museum". A more nuanced response was given by Fifi 
(non-visiting group) who contended: "I believe that [painful] memories can't be healed but they can be eased through the fact that the people who died there are remembered".

While it is claimed that memorial museums can contribute to healing through acts of remembrance [12,13], these students (whether or not they had visited) were unconvinced that Sighet Museum had such a role in healing the painful memories of the communist era. Instead, its role in healing was largely confined to providing comfort (and possibly closure [28]) for the relatives of those who had been imprisoned in Sighet. This perhaps indicates a recognition that the extent of the trauma experienced by those who had lived through communism was such that a museum could make little contribution to social healing. However, it should be noted here that older people with direct experience and memories of the communist era might think in a different way about what a memorial museum can contribute to healing.

Sighet Memorial Museum interprets a period of history which ended more than 30 years ago. This raises the issue of the timescale of transitional justice projects, and specifically how long a memorial museum will remain relevant to its various users. Certainly, the key stakeholders associated with the museum were convinced that the museum continued to be relevant for Romanians. When asked if there was still a need for the museum 30 years after the fall of communism, a former detainee argued the following:

Certainly there is, there is ... and after 50 years and after 100 years there will still be a need for this museum, because if we don't keep it [the communist period] in mind, we could return to where we were 30 years ago. We need to know the past; the past needs to be continually kept in mind, because if you don't know the past, you don't know what you need to do in the future.

(Ioan Ilban, interview)

The museum's founder also spoke of the long-term role of the museum but recognized that its role would change over time:

Paradoxically, I think that as time passes, these testimonies about a fairly long period of history (the traces of which I hope will over time be erased from our history) will be interesting and will exist, and will continue to be visited, just as archaeological sites and classic museums continue to be visited.

(Ana Blandiana, interview)

Both interviews highlighted the importance of long-term remembrance of the human rights abuses of the communist era as a reminder to present and future generations. Both the visiting and non-visiting groups of students were also asked if there was still a need for Sighet Memorial Museum 30 years after the fall of communism. Their responses are presented in Table 6 below.

Table 6. Responses to the question of " 30 years after the fall of communism, is there still a need for museums like Sighet"?

\begin{tabular}{cccc}
\hline & Visiting Group & Non-Visiting Group & Total \\
\hline Yes & 43 & 16 & 59 \\
No & 0 & 0 & 0 \\
Ambivalent & 0 & 2 & 2 \\
Total & 43 & 18 & 61 \\
\hline
\end{tabular}

As Table 6 shows, there was general agreement that there was a continued need for Sighet Memorial Museum. As reported elsewhere [27], the visiting group members were unanimous in this regard, and very similar views were reported by the non-visiting group members (with the only uncertain responses being among this group). The difference between the groups was not statistically significant (Fisher's exact test, $p>0.05$, "no" and "ambivalent" categories combined) and, whether or not they had visited, these young people clearly recognized the importance of memorial museums as instruments of remem- 
brance. As such, their views were aligned with those of the museum's key stakeholders. The focus group responses were focused on two issues. The first was the importance for present and future generations to know about what happened in the communist period [27]. For example, Papa (non-visiting group) highlighted the importance of the museum for his generation: "There's a need for the museum because it shows us, those who weren't alive at the time, the things that happened, and it can make us think about what happened and reflect on those things". Others highlighted the importance of the museum for future generations, such as Bera (non-visiting group), who stated: "It's important, especially because the generations who will follow won't be able to find out (in the same way that we did, by being told by people who lived in that period) about what happened". A second type of response focused on honoring those who suffered under communism but, significantly, this was only mentioned by those who had visited the museum. For example, Didi (visiting group) stated that "it's important in order to see how many people suffered so that we can have what we have today".

These responses indicate that, while many of these young people were unconvinced about the museum's role within broader processes of transitional justice, they fully understood the importance of remembrance. Furthermore, even if they had not visited, they recognized the museum's role in this regard. Once again, they were engaging with the temporal frame of remembrance within transitional justice [36] and they understood that the museum was a resource for (and about) the future as much as being about the past $[13,15,74]$.

\section{Conclusions}

In the context of broader debates about memorialization within transitional justice projects, this paper has examined the impact of a memorial museum through comparing the responses of young people who had and had not visited it. Visiting the museum appeared to have a limited impact on opinions about the recent past. While non-visitors tended to have more negative views, those who had visited were as likely to have ambivalent as negative views about the communist regime. Similarly, the act of visiting did not appear to influence attitudes about the criminal nature of the communist regime, nor was there any significant difference in opinion about whether Romania could experience a period of repression or authoritarianism again (although the visiting group appeared to use different examples to illustrate their position which drew on their experience in the museum). In terms of the museum's role within wider process of transitional justice, these students had mixed views about its contribution to post-communist democratization, but those who had visited were not more likely to consider that the museum could contribute to this end. Whether or not they had visited, most students were skeptical about the contribution of the museum to individual or social healing. There was a consensus on the ongoing need and role of Sighet Museum as a site of remembrance, but there was greater recognition among the visiting group of the importance of remembering the victims of communist repression.

It was apparent that these young people did not visit the museum with tabula rasa. While they had no direct experience of communism, all of these students had developed a wide range of intergenerational memories of, and about, communism. The main source of this knowledge was the stories of their families, and the main locus of transmission was the home. While most were aware of the negative side of communism (particularly restrictions on freedom of speech) many had also heard positive accounts of the communist era. Furthermore, many students had drawn on their own life experiences of uncertainty within post-communist Romania, which they juxtaposed against the stories they had heard from relatives about the "certainties" of communism. The effect of this wide range of background knowledge about the communist period and regime was that the psychological distance between them and the communist past was not especially large.

This background knowledge of communism meant that those in the visiting group had responded to the museum in a range of ways. For some, the museum's emphatic condemnation of communism confirmed their existing views. In other cases, the museum's 
presentation collided with the rather more positive accounts that they had heard within their families about the communist past. In this sense, Sighet Museum was just one among a number of competing sources of information about the communist past. What was clear is that many had not responded to the museum passively or uncritically $[36,69]$ and, in particular, many had not unquestioningly accepted the museum's strenuous condemnation of the communist regime. Instead, the response of many of the visiting group had been more akin to a dialogue with the museum [41] whether or not this was intended by the museum's sponsors. The museum presented them with a clear story about the communist past but, faced with such 'difficult knowledge' [74], they were able to reconcile conflicting accounts of communism and come to their own views about the recent past [27]. They were also able to make their own judgements about what the museum could achieve as an instrument of transitional justice.

These findings have a number of implications concerning the role of memorial museums within transitional justice. It is often claimed that such museums have the potential to lead to transformative personal experiences for their visitors [13,29]; however, at the same time it is also important to be attentive to the limitations of what memorial museums can achieve [15]. As Hamber [36] (p. 273) argued in a related context, "we need to be careful that we do not overstate the ability of conflict museums to affect social or individual change". While Sighet Memorial Museum can clearly provide powerful and moving experiences for its visitors $[26,27]$ its role in shaping or changing the way that young people think about the communist past appears to be more limited. It is also clear that memorial museums such as Sighet can be sites where competing meanings of the past are played out. Memory and remembering are fluid in societies engaged in transitional justice. The period after conflict, repression or authoritarian rule involves a struggle around the meaning of the past and how it should be remembered [11,12]. This means that memory will unfold in complex ways at memorial sites [36]. Memorial museums may seek to shape how the recent past is understood and remembered, but their efforts may be thwarted by visitors who have their own entrance narratives, prior knowledge, and agency so that they can accept, negotiate or reject the presentation of the past which they encounter.

Like any piece of research, this study has a number of limitations. First, as a study of a single museum, these findings will have limited generalizability [21], so there is a need for additional research which explores the issues raised at other memorial museums, in a range of other transitional justice contexts. Second, the participants in this study were all university students, so their responses may not be representative of all young people in Romania. Third, this study has not considered issues such as the political affiliations or ideological preferences of students as factors which may influence attitudes towards the communist past and therefore responses to the museum. Fourth, this study was undertaken with young people who were studying in Timişoara, a town famous in Romania as the place where the 1989 revolution started. This may have influenced attitudes towards the communist regime which may not be shared by students in other parts of Romania. Fifth, the sample sizes (particularly of the non-visiting group) were relatively small, so a study feature a larger sample size may produce different findings.

This study points to a number of directions for future research. First, while there are numerous studies that have examined the messages and display approaches of individual memorial museums, research studies that have directly engaged with visitors to memorial museums established within transitional justice projects are far more scarce [14,26,43-45]. This study has demonstrated the value of directly engaging with visitors (and non-visitors) and understanding their perspectives; however, there is a need to explore (in a wide range of transitional justice contexts) the ways in which visitors encounter and respond to museums interpreting recent political violence. Second, further research could explore responses of a broader range of young people to memorial museums. This might include young adults who are not studying at university, but also younger children who may visit a memorial museum as part of their school curriculum. It could also include those visitors who have lived through repression and past violence [27]. For this group, the psychological 
distance between them and past violence is especially reduced, such that their responses to such sites of memory may be very different. Third, future research might focus in more detail on intergenerational family memories of past political violence and the ways in which such memories can influence the response of young people to the history displayed in a memorial museum. This issue is important because it may have an important influence on what such a museum is able to achieve. Finally, the ways in which memorial museums can contribute to transitional justice projects is widely assumed, but rarely researched. Future research could examine the contributions of memorial museums to reconciliation and individual/social healing. This, in turn, would allow the development of a fuller understanding of the role, contribution, and limitations of memorialization initiatives within transitional justice projects.

Author Contributions: Conceptualization: D.L., R.C. and A.-M.D.; methodology: D.L., R.C. and A.M.D.; data collection and curation: R.C. and A.-M.D.; data analysis: D.L. and R.C.; writing-original draft preparation: D.L. and R.C.; revised draft preparation: D.L. and R.C. All authors have read and agreed to the published version of the manuscript.

Funding: This research received no external funding.

Institutional Review Board Statement: Informed consent was obtained from all subjects involved in the study. The study was approved through the research ethics review process at Bournemouth University (reference number 17981, approved on 12 December 2017; reference number 17989, approved on 2 May 2018).

Informed Consent Statement: Informed consent was obtained from all subjects involved in the study. The study was approved through the research ethics review process at Bournemouth University.

Data Availability Statement: The data presented in this study are available on request from the corresponding author. The data are not publicly available since at the time of requesting consent from participants we did not request permission to make focus groups/interview transcripts publicly available.

Acknowledgments: We express our thanks to the 61 students from West University of Timişoara for willingly taking part in our focus group sessions. We are also grateful to Ana Blandiana, Ioana Boca, and Ioan Ilban for generously granting us interviews. We are also grateful to the reviewers of this paper for their constructive and useful feedback.

Conflicts of Interest: The authors declare no conflict of interest.

\section{References}

1. Erll, A. Cultural memory studies: An introduction. In Cultural Memory Studies: An International and Interdisciplinary Handbook; Erll, A., Nünning, A., Eds.; Walter de Gruyter: Berlin, Germany, 2008; pp. 1-15, ISBN 9783110188608.

2. Laanes, E.; Meretoja, H. Editorial: Cultural memory forms. Mem. Stud. 2021, 14, 3-9. [CrossRef]

3. Halbwachs, M. On Collective Memory; Coser, L.A., Trans.; University of Chicago Press: Chicago, IL, USA, 1992; ISBN 9780226115962.

4. Nora, P. Between memory and history: Les Lieux de Mémoire. Representations 1989, 26, 7-13. [CrossRef]

5. Foote, K.; Azaryahu, M. Toward a geography of memory: Geographical dimensions of public memory and commemoration. J. Political Mil. Sociol. 2007, 35, 124-144.

6. Ciobanu, M. Repression, Resistance and Collaboration in Stalinist Romania, 1944-1964: Post-Communist Remembering; Routledge: Abingdon, UK, 2021; ISBN 9781138089204.

7. Stan, L. Transitional Justice in Post-Communist Romania: The Politics of Memory; Cambridge University Press: Cambridge, UK, 2013; ISBN 9781107020535.

8. Nedelsky, N.; Stan, L. Introduction: Post-communist Transitional Justice at 25. In Post-Communist Transitional Justice: Lessons from Twenty-Five Years of Experience; Stan, L., Nedelsky, N., Eds.; Cambridge University Press: New York, NY, USA, 2015; pp. 1-4, ISBN 9781107588516.

9. De Brito, A.B. Transitional Justice and Memory: Exploring Perspectives. South Eur. Soc. Politics 2010, 15, 359-376. [CrossRef]

10. Barsalou, J.; Baxter, V. The Urge to Remember: The Role of Memorials in Social Reconstruction and Transitional Justice; United States Institute of Peace: Washington, DC, USA, 2007. Available online: https://www.usip.org/sites/default/files/resources/srs5.pdf (accessed on 24 March 2021).

11. Jelin, E. Public Memorialization in Perspective: Truth, Justice and Memory of Past Repression in the Southern Cone of South America. Int. J. Transit. Justice 2007, 1, 138-156. [CrossRef] 
12. Brown, K. Commemoration as Symbolic Reparation: New Narratives or Spaces of Conflict? Hum. Rights Rev. 2013, 14, 273-289. [CrossRef]

13. Sodaro, A. Exhibiting Atrocity: Memorial Museums and the Politics of Past Violence; Rutgers University Press: New Brunswick, NJ, USA, 2018; ISBN 9780813592138.

14. Balcells, L.; Palanza, V.; Voytas, E. Do Transitional Justice Museums Persuade Visitors? Evidence from a Field Experiment. Forthcom. J. Politics 2020, accepted. Available online: https: / / ssrn.com/abstract=3687658 (accessed on 31 March 2021).

15. Williams, P. Memorial Museums: The Global Rush to Commemorate Atrocities; Berg: Oxford, UK, 2007 ; ISBN 9781845204891.

16. Carter, J.; Orange, J. Contentious Terrain: Defining a Human Rights Museology. Mus. Manag. Curatorship 2012, $27,111-127$. [CrossRef]

17. Ibhawoh, B. Commemorating Human Rights: Exploring Origins, Episodes, and Historicity in Constructing a Human Rights Timeline. Peace Confl. 2013, 19, 338-348. [CrossRef]

18. Tamashiro, R.; Furnari, E. Museums for Peace: Agents and Instruments of Peace Education. J. Peace Educ. 2015, 12, 223-235. [CrossRef]

19. Chen, C.-L. Introducing Human Rights Education within a Memorial Museum Framework: The Challenges and Strategies of Taiwan's National Human Rights Museums. Mus. Manag. Curatorship 2019, 34, 562-576. [CrossRef]

20. Bonacker, T.; Buckley-Zistel, S. Introduction: Transitions from Violence-Analyzing the Effects of Transitional Justice. Int. J. Confl. Violence 2013, 7, 4-9. [CrossRef]

21. Bunselmeyer, E.; Schulz, P. Quasi-experimental Research Designs as a Tool for Assessing the Impact of Transitional Justice Instruments. Int. J. Hum. Rights 2020, 24, 688-709. [CrossRef]

22. Duggan, C. Editorial Note. Int. J. Transit. Justice 2010, 4, 315-328. [CrossRef]

23. Duggan, C. "Show Me Your Impact": Evaluating Transitional Justice in Contested Spaces. Eval. Program Plan. 2012, 35, 199-205. [CrossRef] [PubMed]

24. Gready, P.; Robins, S. Transitional Justice and Theories of Change: Towards Evaluation as Understanding. Int. J. Transit. Justice 2020, 14, 280-299. [CrossRef]

25. Hamber, B.; Ševĉenko, L.; Naidu, E. Utopian Dreams or Practical Possibilities? The Challenges of Evaluating the Impact of Memorialization in Societies in Transition. Int. J. Transit. Justice 2010, 4, 397-420. [CrossRef]

26. Cretan, R.; Light, D.; Richards, S.; Dunca, A.-M. Encountering the Victims of Romanian Communism: Young People and Empathy in a Memorial Museum. Eurasian Geogr. Econ. 2018, 59, 632-656. [CrossRef]

27. Light, D.; Cretan, R.; Duncan, A.-M. Education and Post-communist Transitional Justice: Negotiating the Communist Past in a Memorial Museum. Southeast Eur. Black Sea Stud. 2019, 19, 565-584. [CrossRef]

28. Clark, L.B. Never Again and its Discontents. Perform. Res. 2011, 16, 68-79. [CrossRef]

29. Soren, B.J. Museum Experiences that Change Visitors. Mus. Manag. Curatorship 2009, 24, 233-251. [CrossRef]

30. Simon, R.I. A Shock to Thought: Curatorial Judgement and the Public Exhibition of 'Difficult Knowledge'. Mem. Stud. 2011, 4, 432-449. [CrossRef]

31. Zombory, M. Visualizing Revisionism: Europeanized Anticommunism at the House of Terror Museum in Budapest. In Museums of Communism: New Memory Sites in Central and Eastern Europe; Norris, S.M., Ed.; Indiana University Press: Bloomington, IN, USA, 2020; pp. 47-77.

32. Violi, P. Trauma Site Museums and Politics of Memory: Tuol Sleng, Villa Grimaldi and the Boogna Ustica Museum. Theory Cult. Soc. 2012, 29, 36-75. [CrossRef]

33. Zalut, L. Interpreting Trauma, Memory, and Lived Experience in Museums and Historic Sites. J. Mus. Ed. 2018, 43, 4-6. [CrossRef]

34. Witcomb, A. Understanding the Role of Affect in Producing a Critical Pedagogy for History Museums. Mus. Manag. Curatorship 2013, 28, 255-271. [CrossRef]

35. Cole, E. No Legacy for Transitional Justice Efforts without Education; International Center for Transitional Justice: New York, NY, USA, 2017. Available online: https://www.ictj.org/sites/default/files/Transitional_Justice_Legacy_Education.pdf (accessed on 24 March 2021).

36. Hamber, B. Conflict Museums, Nostalgia, and Dreaming of Never Again. Peace Confl. 2012, 18, 268-281. [CrossRef]

37. McGhie, H.; Mander, S.; Minns, A. The Time Machine: Challenging Perceptions of Time and Place to Enhance Climate Change Engagement through Museums. Mus. Soc. 2020, 18, 183-197. [CrossRef]

38. Massara, F.; Severino, F. Psychological Distance in the Heritage Experience. Ann. Tour. Res. 2013, 42, 108-129. [CrossRef]

39. Trope, Y.; Liberman, N.; Wakslak, C. Construal Levels and Psychological Distance: Effects on Representation, Prediction, Evaluation and Behavior. J. Consum. Psychol. 2007, 17, 83-95. [CrossRef]

40. Ying, Y.; Tan, T.; Ye, S.; Ka, X.; Zhou, Y. Examining Tourist Mindfulness in Museums: The Roles of Familiarity and Motivation. Asia Pac. J. Tour. Res. 2020, 25, 981-996. [CrossRef]

41. Trofanenko, B.M. On Difficult History Displayed: The Pedagogical Challenges of Interminable Learning. Mus. Manag. Curatorship 2011, 26, 481-495. [CrossRef]

42. Norris, S. (Ed.) Museums of Communism: New Memory Sites in Central and Eastern Europe; Indiana University Press: Bloomington, IN, USA, 2020; ISBN 9780253050328. 
43. Bickford, L. Transforming a Legacy of Genocide: Pedagogy and Tourism at the Killing Fields or Choeung Ek; International Center for Transitional Justice: New York, NY, USA, 2009. Available online: https://www.ictj.org/sites/default/files/ICTJ-CambodiaLegacy-Genocide-2009-English.pdf (accessed on 24 March 2021).

44. Balcells, L.; Palanza, V.; Voytas, E. Do Museums Promote Reconciliation? A Field Experiment on Transitional Justice; Empirical Studies of Conflict Working Paper No. 10; Princeton University: Princeton, NJ, USA, 2018. Available online: https:/ / esoc.princeton.edu/ publications / esoc-working-paper-10-do-museums-promote-reconciliation-field-experiment-transitional (accessed on 24 March 2021).

45. Lleras, C.; González-Ayala, S.N.; Botero-Mejía, J.; Velandia, C.M. Curatorship for Meaning Making: Contributions towards Symbolic Reparation at the Museum of Memory of Columbia. Mus. Manag. Curatorship 2019, 34, 544-561. [CrossRef]

46. Swim, J.; Geiger, N.; Fraser, J.; Pletcher, N. Climate Change Education at Nature-based Museums. Curator 2017, 60, 101-119. [CrossRef]

47. Stan, L. Neither Forgiving nor Punishing? Evaluating Transitional Justice in Romania. In After Oppression: Transitional Justice in Latin America and Eastern Europe; Popovski, V., Serrano, M., Eds.; United Nations University Press: Tokyo, Japan, 2012; pp. 363-389, ISBN 9789280812008.

48. Cristea, G.; Radu-Bucurenci, S. Raising the Cross: Exorcising Romania's Communist Past in Museums, Memorial and Monuments. In Past for the Eyes: East European Representations of Communism in Cinema and Museums after 1989; Sarkisova, O., Apor, P., Eds.; Central European University Press: Budapest, Hungary, 2008; pp. 175-305, ISBN 9789639776036.

49. Willson, V.L.; Kim, E.S. Pretest Sensitization. In Encyclopedia of Research Design Volume 1; Salkind, N.J., Ed.; Sage: London, UK, 2010; pp. 1091-1094, ISBN 9781412961288.

50. Marsden, E.; Torgerson, C.J. Single Group, Pre- and Post-Test Research Designs: Some Methodological Concerns. Oxf. Rev. Educ. 2012, 38, 583-616. [CrossRef]

51. Pattison, S.; Gutwill, J.; Auster, R.; Cannady, M. Experimental and Quasi-experimental Design in Visitor Studies: A Critical Reflection on Three Projects. Visit. Stud. 2019, 22, 43-66. [CrossRef]

52. Gill, J.K.; Walsh, J. Control Group. In Encyclopedia of Research Design Volume 1; Salkind, N.J., Ed.; Sage: London, UK, 2010; p. 251, ISBN 9781412961271.

53. Fu, A.C.; Kannan, A.; Shavelson, R.J.; Peterson, L.; Kurpius, A. Room for Rigor: Designs and Methods in Informal Science Education Evaluation. Visit. Stud. 2016, 19, 12-38. [CrossRef]

54. Betts, D.J.; Potash, J.S.; Luke, J.J.; Kelso, M. An Art Therapy Study of Visitor Reactions to the United States Holocaust Memorial Museum. Mus. Manag. Curatorship 2015, 30, 21-43. [CrossRef]

55. Bowen, D.H.; Kisida, B. Never Again: The Impact of Learning about the Holocaust on Civic Outcomes. J. Res. Educ. Eff. 2020, 13, 67-91. [CrossRef]

56. Litosseliti, L. Using Focus Groups in Research; Continuum: London, UK, 2003; ISBN 9781441141804.

57. Rubenstein, R. The Use of Focus Groups in Audience Research. In Visitor Studies: Theory, Research and Practice. Proceedings of the 1988 Visitor Studies Conference Volume 1; Bitgood, S., Ed.; Visitor Studies Association: Albany, NY, USA, 1989; pp. $180-188$.

58. Steele, C.; Andrews, H.; Upton, D. Statistics for Psychology; Prentice-Hall: Harlow, UK, 2012; ISBN 9780273738107.

59. Madrigal, L. Statistics for Anthropology; Cambridge University Press: Cambridge, UK, 2012; ISBN 9780521147088.

60. Bryman, A. Social Research Methods, 5th ed.; Oxford University Press: Oxford, UK, 2016; ISBN 9780199689453.

61. Ekman, J.; Linde, J. Communist nostalgia and the consolidation of democracy in Central and Eastern Europe. J. Communist Stud. Transit. Politics 2005, 21, 354-374. [CrossRef]

62. Besliu, R. Communist Nostalgia in Romania. Available online: https://www.opendemocracy.net/en/can-europe-make-it/ communist-nostalgia-in-romania/ (accessed on 24 March 2021).

63. Rusu, M.S. Battling over Romanian Red Past: The Memory of Communism between Elitist Cultural Trauma and Popular Collective Nostalgia. Rom. J. Soc. Politics 2015, 10, 24-48.

64. Marin, M. Assessing Communist Nostalgia in Romania: Chronological Framework and Opinion Polls. Twent. Century Communism 2016, 11, 10-26. [CrossRef]

65. Arun, G. Tinerii şi Provocarea Trecutului. 2011. Available online: https://www.dw.com/ro/tinerii-\%C5\%9Fi-provocareatrecutului/a-14985120 (accessed on 24 March 2021).

66. Morariu, M. From Condemnation to Melancholy: Alternative Meanings of Post-Communist Nostalgia in Romania Beyond the Official Anti-Communist Discourse. Studia Politica Rom. Political Sci. Rev. 2012, 12, 289-308.

67. Europa, F.M. Aproape 60\% Dintre Tinerii Români Cred că era Mai Bine în Communism. 2019. Available online: https:/ /www. europafm.ro/o-femeie-din-iasi-a-murit-la-nastere-din-cauza-unei-boli-rare/ (accessed on 24 March 2021).

68. Nikolayenko, O. Contextual Effects on Historical Memory: Soviet Nostalgia among Post-Soviet Adolescents. Communist Post-Communist Stud. 2008, 41, 243-259. [CrossRef]

69. Falk, J.H.; Dierking, L.D. The Museum Experience Revisited; Left Coast Press: Walnut Creek, CA, USA, 2013; ISBN 9781611320442.

70. Hirsch, M. Family Pictures: Maus, Mourning, and Post-memory. Discourse 1992, 15, 3-29. Available online: www.jstor.org/stable/ 41389264 (accessed on 16 March 2021).

71. Hirsch, M. The Generation of Postmemory. Poet. Today 2008, 29, 103-128. [CrossRef]

72. Văran, C.; Creţan, R. Place and the Spatial Politics of Intergenerational Remembrance of the Iron Gates Displacements in Romania, 1966-1972. Area 2017, 50, 509-519. [CrossRef] 
73. Wildschut, T.; Sedikides, C.; Robertson, S. Sociality and Intergenerational Transfer of Older Adults' Nostalgia. Memory 2018, 26, 1030-1041. [CrossRef]

74. Simon, R.I. The Terrible Gift: Museums and the Possibility of Hope without Consolation. Mus. Manag. Curatorship 2006, 21, 187-204. [CrossRef] 